\title{
PENGELOLAAN PERIKANAN CAKALANG YANG DIDARATKAN DI PELABUHAN PERIKANAN NUSANTARA (PPN) PRIGI, TRENGGALEK: APLIKASI FEEDBACK HARVEST CONTROL RULE
}

\author{
Fishery Management of Skip Jack Tuna Landed in Prigi Fishing Port, Trenggalek: \\ Feedback Harvest Control Rule Application
}

Oleh:
Ledhyane Ika Harlyan¹, Wahida Kartika Sari², Farisa Mardiana Rahma ${ }^{3}$, Fuad4, Muhammad Arif Rahman ${ }^{5}$

\footnotetext{
${ }^{1}$ Fakultas Perikanan dan Ilmu Kelautan, Universitas Brawijaya.ledhyane@ub.ac.id

2 Fakultas Perikanan dan Ilmu Kelautan, Universitas Brawijaya.wahidaks@ub.ac.id

3 Fakultas Perikanan dan Ilmu Kelautan, Universitas Brawijaya.farisa.hrn@gmail.com

${ }^{4}$ Fakultas Perikanan dan Ilmu Kelautan, Universitas Brawijaya.fuad@ub.ac.id

${ }_{5}^{5}$ Fakultas Perikanan dan Ilmu Kelautan, Universitas Brawijaya.arifelzain@ub.ac.id
}

* Korespondensi:ledhyane@ub.ac.id

Diterima: 28 Februari 2021; Disetujui: 1 April 2021

\begin{abstract}
Skip jack tuna (Katsuwonus pelamis) is one of the leading export commodities landed at the Prigi Fishing Port (PPN Prigi). Conventional single-species Schaefer model is often applied as a fishery management tool, though it is not technically suitable for multispecies fishery. The application of feedback harvest control rule $(H C R)$ is an alternative harvest strategy that has been successfully implemented and validated for multispecies fishery. This study estimated allowable biological catch by applying two harvest strategies, HCR feedback and Schaefer surplus production model using catch-effort data of skipjack tuna landed at PPN Prigi in the period $2010-2019$. Applying Schaefer model for Skip jack tuna for years still resulted that catches have exceeded the maximum sustainable yield (MSY) even employed lower the fishing effort which was under the fishing mortality consistent with achieving MSY (f_MSY) than that of applying feedback HCR. Therefore, the application of feedback HCR that has been previously validated can be an alternative of harvest strategy for use in fisheries where only mixed species data is available.
\end{abstract}

Keywords: multispecies fishery, harvest strategy, Schaefer model, maximum sustainable yield, single-species approach.

\section{ABSTRAK}

Cakalang (Katsuwonus pelamis) merupakan salah satu komoditas ekspor unggulan yang didaratkan di Pelabuhan Perikanan Nusantara (PPN) Prigi. Pengelolaan perikanan cakalang dengan menggunakan model konvensional spesies tunggal Schaefer kerap digunakan meski secara teknis tidak sesuai digunakan pada perikanan multispesies. Aplikasi feedback harvest control rule $(H C R)$ merupakan alternatif strategi penangkapan yang sukses diterapkan dan tervalidasi dapat digunakan untuk perikanan multispesies. Pada penelitian ini dilakukan kajian estimasi jumlah tangkapan yang aman secara biologis untuk dimanfaatkan dengan menggunakan dua strategi penangkapan yaitu feedback HCR dan model surplus produksi Schaefer dengan menggunakan data hasil tangkapan dan upaya penangkapan perikanan cakalang yang didaratkan di PPN Prigi dalam kurun waktu 2010 - 2019. Pengelolaan perikanan cakalang dengan model 
Schaefer selama bertahun-tahun tetap menunjukkan bahwa hasil tangkapan yang didaratkan telah melampaui poin referensi hasil tangkapan lestari (maximum sustainable yield/MSY) meski dengan referensi nilai upaya penangkapan $\left(f_{M S Y}\right)$ yang lebih rendah dari pada penggunaan aplikasi feedback HCR. Aplikasi feedback HCR yang telah sebelumnya tervalidasi dapat menjadi alternatif strategi pengelolaan perikanan untuk digunakan pada perikanan dimana hanya tersedia data spesies tercampur dapat menjadi salah satu alternatif strategi pengelolaan dengan kebutuhan data yang relatif praktis.

Kata kunci: perikanan multispesies, strategi penangkapan, model Schaefer, hasil tangkapan lestari, pendekatan spesies tunggal

\section{PENDAHULUAN}

Wilayah Pengelolaan Perikanan Negara Indonesia (WPP NRI) 573 merupakan wilayah pengelolaan yang kaya akan beberapa spesies ekonomis penting. Berdasarkan Permen No. 18 Tahun 2014 tentang Wilayah Pengelolaan Perikanan, WPP 573 meliputi perairan Samudera Hindia sebelah selatan Jawa hingga sebelah selatan Nusa Tenggara, Laut Sawu, dan Laut Timor bagian barat (Kementerian Kelautan dan Perikanan 2014). Perairan Prigi yang merupakan cakupan dari wilayah perairan Samudera Hindia bagian selatan Jawa merupakan perairan penghasil salah satu komoditas perikanan ekspor unggulan Indonesia yaitu sumber daya ikan (SDI) cakalang (Katsuwonus pelamis) (Asia et al. 2019).

Sebagai salah satu komoditas unggulan, cakalang berkontribusi sebesar $14,23 \%$ dari total ekspor perikanan Indonesia (Kementerian Kelautan dan Perikanan 2020). Berdasarkan Keputusan Menteri Kelautan dan Perikanan Nomor 47 Tahun 2016 tentang estimasi potensi, jumlah tangkapan yang diperbolehkan, dan tingkat pemanfaatan SDI di WPP NRI, tingkat pemanfaatan SDI pelagis besar telah mencapai 0,73 yang berarti telah dimanfaatkan secara penuh. Pengupayaan penangkapan dapat dipertahankan dengan monitor ketat (Kementerian Kelautan dan Perikanan 2016). Rasio eksploitasi penangkapan tersebut meningkat hampir $50 \%$ dari sebelumnya dengan status moderate dimana prinsip kehatihatian mutlak diperlukan dalam pengelolaan perikanan pelagis yang lestari.

Adanya peningkatan resiko pemanfaatan berlebihan atas SDI cakalang menyita perhatian pemerintah dan peneliti perikanan. Beberapa penelitian terkait estimasi potensi, tingkat pemanfaatan, beserta jumlah tangkapan yang diperbolehkan untuk SDI cakalang di Perairan Prigi telah dilakukan dalam kurun waktu 10 tahun terakhir (Setiyawan and Haryuni 2013; Setiyawan 2016; Ma'mun et al. 2017) dengan menggunakan pendekatan model surplus produksi.

Model surplus produksi sebagai metode estimasi stok ikan konvensional kerap digunakan di seluruh dunia, tak terkecuali pada perairan multispesies (Hilborn and Ovando 2014; Newman et al. 2018; Harlyan et al. 2019). Model ini mensyaratkan tersedianya informasi biologi spesifik untuk setiap spesies (Hilborn and Walters 1992; Cadrin and Dickey-Collas 2015). Oleh karena itu, secara teknis model surplus produksi tidak sesuai digunakan pada perikanan multispesies atau perikanan dengan data perikanan yang tidak spesifik (Shertzer et al. 2008). Pada perikanan tropis yang umumnya bersifat multispesies, asumsi pendekatan spesies tunggal relatif sulit dipenuhi karena penggunaan beragam alat tangkap dan menangkap beragam kelompok spesies (Harlyan et al. 2021). Faktanya, pengelolaan perikanan tetap didasarkan pada model yang lebih sesuai digunakan pada perairan sub-tropis, dimana hasil tangkapan lestari (maximum sustainable yield/MSY) dihitung hanya untuk beberapa spesies kunci. Selain itu, keterbatasan teknis dan finansial untuk melakukan pemisahan spesies juga merupakan alasan ketidaktersediannya data spesies yang spesifik (Yuniarta et al. 2017).

Aplikasi feedback harvest control rule (HCR) (Tanaka 1980; Ohshimo and Naya 2014) merupakan strategi penangkapan yang sukses diterapkan pada pengelolaan perikanan Jepang (Ichinokawa et al. 2017). Feedback HCR diperkenalkan pada tahun 1997 sebagai salah satu instrumen pengelolaan perikanan untuk stok ikan tanpa dilengkapi estimasi biomass (Makino 2011). Metode ini 
mampu memberikan rekomendasi saintifik untuk kuota tangkapan tahunan (jumlah tangkapan yang diperbolehkan/JTB) dengan mempertimbangkan kelimpahan stok sebelumnya untuk memperoleh hasil tangkapan di tahun berikutnya. Pada strategi feedback, SDI diasumsikan sebagai sistem kontrol dengan kuota tangkapan sebagai luaran dan kelimpahan stok sebagai masukan, sehingga kuota tangkapan diatur berdasarkan kelimpahan stok (Magnusson 1992). Oleh karena itu, penggunaan feedback HCR pada pengelolaan perikanan mampu memberikan keseimbangan ukuran stok dan menjamin keberlangsungan pemanfaatan SDI (Hoshino et al. 2012, Ohshimo and Naya 2014; Harlyan et al. 2019).

Pada kajian ini dilakukan estimasi jumlah tangkapan yang diperbolehkan untuk pengelolaan perikanan cakalang di perairan Prigi, Trenggalek dengan menggunakan feedback $H C R$ yang sebelumnya telah tervalidasi mampu digunakan untuk perikanan multispesies (Harlyan et al. 2019). Komparasi hasil estimasi akan dilakukan dengan penggunaan model surplus produksi dengan didasarkan pada prinsip kehati-hatian.

\section{METODE}

\section{Sumber Data}

Data yang digunakan dalam penelitian ini ialah data sekunder berupa data hasil tangkapan $(\mathrm{kg})$ dan upaya penangkapan (hari melaut) perikanan cakalang yang didaratkan di Pelabuhan Perikanan Nusantara (PPN) Prigi (Gambar 1) pada tahun 2010-2019. Jumlah hari melaut per tahun dihitung per alat tangkap yang digunakan untuk menangkap SDI cakalang. Terdapat lima alat tangkap yang dioperasikan untuk menangkap cakalang yaitu: purse seine, gillnet, payang, pancing tonda dan pancing ulur.

\section{Analisis Data}

1. Hasil tangkapan per unit upaya

Nilai hasil tangkapan per unit upaya (catch per unit effort/CPUE) menunjukkan indeks kelimpahan stok SDI cakalang yang dihitung dengan formula (Sparre and Venema 1992):

$C P U E=\frac{C}{f}$

dengan:

$C P U E=$ hasil tangkapan per unit upaya pada tahun $\mathrm{ke}$ - (kg/hari)

$C=$ hasil tangkapan pada tahun ke(kg)

$f \quad=$ upaya penangkapan pada tahun ke- (hari)

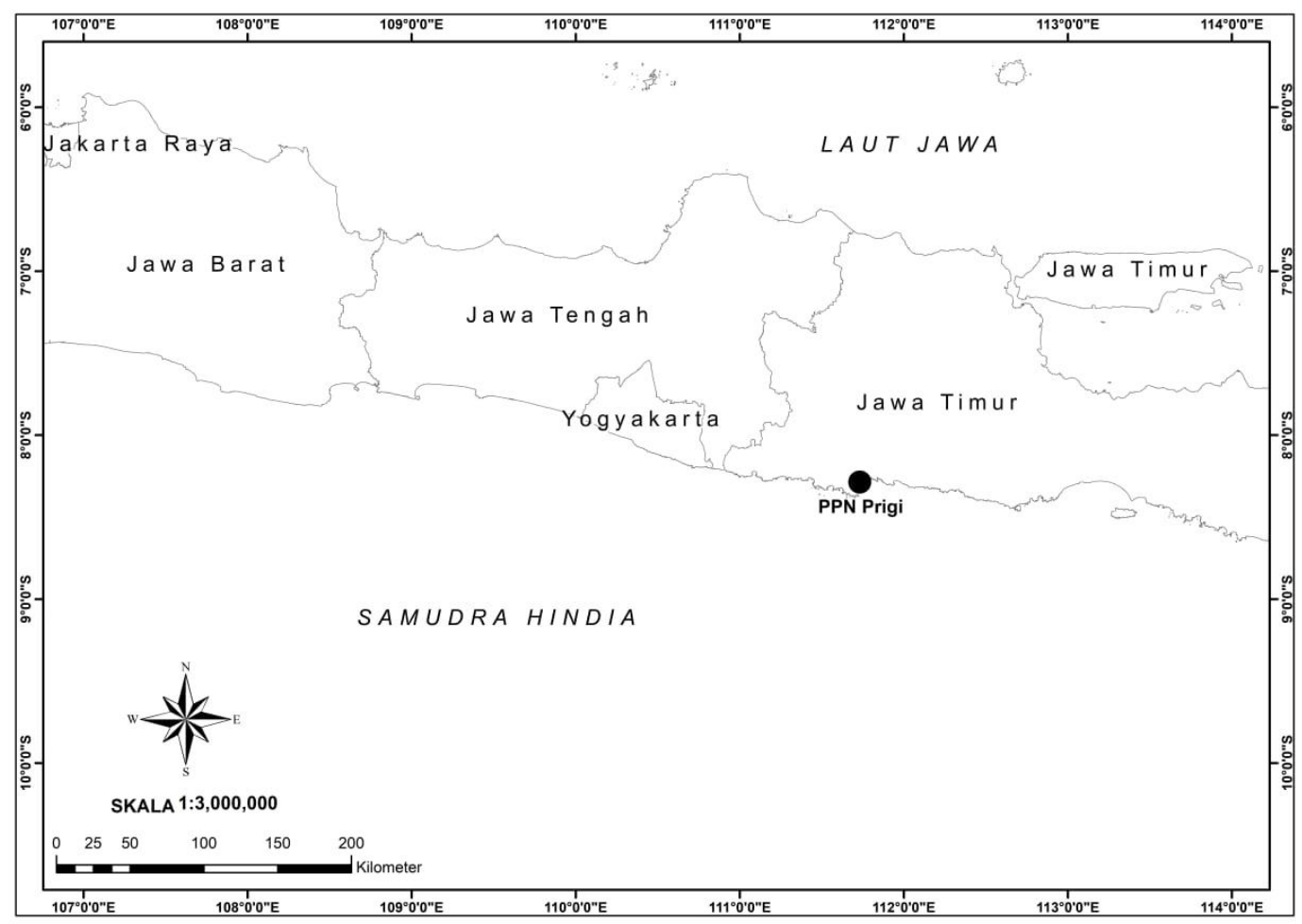

Gambar 1 Peta Lokasi Penelitian 


\section{Strategi Penangkapan}

Estimasi jumlah tangkapan yang diperbolehkan (JTB) dilakukan dengan mengaplikasikan dua strategi penangkapan pada data hasil tangkapan cakalang dan upaya penangkapan yang telah distandarisasi, yaitu:

\section{a. Feedback HCR}

Perhitungan feedback HCR akan menghasilkan estimasi jumlah tangkapan yang aman secara biologi untuk dimanfaatkan pada tahun ke-y (allowable biological catch/ABC ) (Harlyan 2019) dengan menggunakan formula sebagai berikut:

$A B C_{y}=\delta \times C_{y-2} \times \gamma$

$\gamma=\left(1+k \frac{b}{I}\right)$

dengan:

$\delta=$ koefisien pembobotan bernilai 1 untuk level stok tinggi dan sedang; dan 0,5 untuk level stok rendah. Level stok diketahui dari tren indeks kelimpahan stok yaitu dalam hal ini adalah tren CPUE dalam kurun waktu 2010-2019. Penentuan level tinggi, sedang dan rendah dilakukan dengan mencari nilai batas atas dan batas bawah indeks kelimpahan stok, yang diperoleh dari nilai selisih nilai maksimum dan nilai minimum dengan nilai interval dari CPUE. Level stok dikatakan tinggi jika nilai CPUE berada di atas garis batas atas, sedang jika berada di antara garis batas atas dan bawah, dan rendah jika berada di bawah garis batas bawah.

$C_{y-2}=$ hasil tangkapan pada tahun $y-2(\mathrm{~kg})$

$k=$ feedback factor (bernilai 1)

$\gamma=$ tren CPUE dalam kurun waktu 2010 2019

$b=$ koefisien regresi (slope) CPUE dari tahun $y-4$ hingga $y-2$

$I$ = rata-rata $C P U E$ pada tahun $y-4$ hingga $y-2(\mathrm{~kg} /$ hari)

\section{b. Model surplus produksi Schaefer}

Perhitungan model surplus produksi Schaefer bertujuan untuk menentukan tingkat upaya penangkapan yang optimum dimana upaya penangkapan tersebut mampu memberikan nilai $M S Y$ tanpa berdampak pada produktivitas stok di tahun-tahun mendatang (Sparre and Venema 1992). Formula model ini menggunakan analisis regresi linier antara hasil tangkapan per unit upaya dan upaya penangkapan yaitu sebagai berikut:
$\frac{C}{f}=a-b f$

$f_{M S Y}=\frac{a}{2 b}$

$C_{M S Y}=\frac{a^{2}}{4 b}$

dengan:

$a=$ intersep

$b=$ koefisien regresi (slope)

$f_{M S Y}=$ upaya penangkapan yang akan menghasilkan hasil tangkapan lestari (hari)

$C_{M S Y}=$ hasil tangkapan lestari $(\mathrm{kg})$

3. Perbandingan strategi penangkapan feedback HCR dan model surplus produksi Schaefer dilakukan dengan menganalisis prinsip kehati-hatian yang dihasilkan dari estimasi JTB untuk kedua strategi penangkapan tersebut.

\section{HASIL}

Data statistik perikanan cakalang yang didaratkan di PPN Prigi selama kurun waktu 2010-2019 menunjukkan adanya penurunan produksi perikanan cakalang dalam 10 tahun terakhir (Tabel 1).

Berdasarkan data yang tercantum pada Tabel 1, perhitungan JTB dilakukan dengan menggunakan dua strategi penangkapan yaitu aplikasi feedback HCR dan metode surplus produksi Schaefer.

\section{Feedback HCR}

Berdasarkan perhitungan level stok $(\delta)$ yang diperoleh dari tren stok dalam kurun waktu 2010-2019 menunjukkan berada pada level rendah yang bernilai 0,5 (Gambar 2). Hasil tangkapan SDI cakalang pada dua tahun sebelum tahun estimasi $\left(C_{y-2}\right)$ yaitu sebesar $563.529 \mathrm{~kg}$. Koefisien regresi untuk tren $C P U E_{(y-2)-(y-4)}$ selama kurun waktu 2016 - 2019 adalah sebesar 0.98, sedangkan rata-rata tren CPUE $(y-2)-(y-4)$ adalah $334,36 \mathrm{~kg} /$ hari.

Dari perhitungan di atas, maka dihasilkan nilai JTB yang aman secara biologi untuk dapat dimanfaatkan $\left(A B C_{2021}\right)$ adalah sebesar $561.875,21 \mathrm{~kg}$ dan besaran upaya penangkapan hari yang dapat dilakukan pada tahun $2021\left(A B E_{2021}\right)$ adalah sebesar 1.809 hari. 
Model surplus produksi Schaefer

Estimasi hubungan hasil tangkapan per unit upaya perikanan cakalang selama kurun waktu 2010-2019 terhadap upaya penangkapan menunjukkan adanya korelasi negatif (Gambar 3).

Model regresi yang dihasilkan memberikan koefisien determinasi sebesar 0,68 yang menunjukkan upaya penang-kapan mampu mempengaruhi variabilitas hasil tangkapan per unit upaya pada perikanan cakalang sebesar $68 \%$. Sebesar $32 \%$ variabilitas tersebut disebabkan oleh faktor lain yang tidak masuk dalam objek penelitian. Persamaan model regresi menunjukkan bahwa peningkatan jumlah hari melaut sebesar 1 hari akan menu-runkan hasil tangkapan per unit upaya sebesar $0,4 \mathrm{~kg} / \mathrm{hari}$.
Berdasarkan nilai intersep (a) sebesar 1028,33 dan koefisien regresi (b) sebesar 0,4 maka diperoleh nilai hasil tangkapan lestari $C_{M S Y}$ sebesar $655.264,42$ $\mathrm{kg}$ dan $f_{M S Y}$ sebesar 1274 hari melaut (Gambar 4). Merujuk pada perhitungan tersebut, hasil tangkapan SDI cakalang telah melewati nilai $C_{M S Y}$ dan jumlah hari melaut yang digunakan nelayan lima alat tangkap untuk menangkap SDI cakalang telah melebihi nilai $f_{M S Y}$.

\section{Perbandingan teknis antara dua strategi penangkapan}

Nilai JTB yang aman secara biologi $\left(C_{0.8 \mathrm{MSY}}\right)$ sebagai hasil dari kedua strategi penangkapan tersebut terlihat pada Tabel 2.

Tabel 1 Data hasil tangkapan dan upaya penangkapan perikanan cakalang

\begin{tabular}{rcccc}
\hline No & Tahun & $\begin{array}{c}\text { Hasil Tangkapan }(\boldsymbol{C}) \\
\mathbf{( k g )}\end{array}$ & $\begin{array}{c}\text { Upaya Penangkapan }(\boldsymbol{f}) \\
\text { (hari) }\end{array}$ & CPUE \\
\hline 1 & 2010 & $763.254,0$ & 1.364 & 559.51 \\
2 & 2011 & $717.189,0$ & 1.621 & 442.48 \\
3 & 2012 & $616.740,0$ & 1.383 & 446.06 \\
4 & 2013 & $584.283,0$ & 1.431 & 408.44 \\
5 & 2014 & $574.219,8$ & 1.588 & 361.60 \\
6 & 2015 & $569.188,1$ & 1.667 & 341.50 \\
7 & 2016 & $564.156,5$ & 1.706 & 330.67 \\
8 & 2017 & $563.842,8$ & 1.745 & 323.03 \\
9 & 2018 & $563.685,9$ & 1.511 & 372.99 \\
10 & 2019 & $563.529,0$ & 1.813 & 310.74 \\
\hline
\end{tabular}

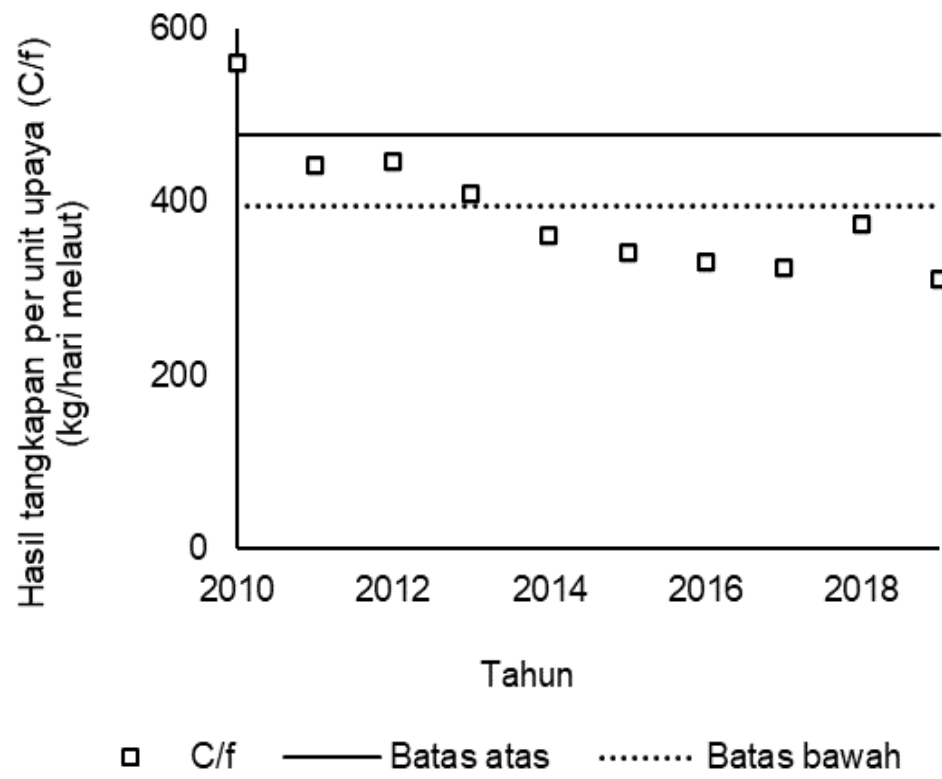

Gambar 2 Level stok SDI Cakalang 


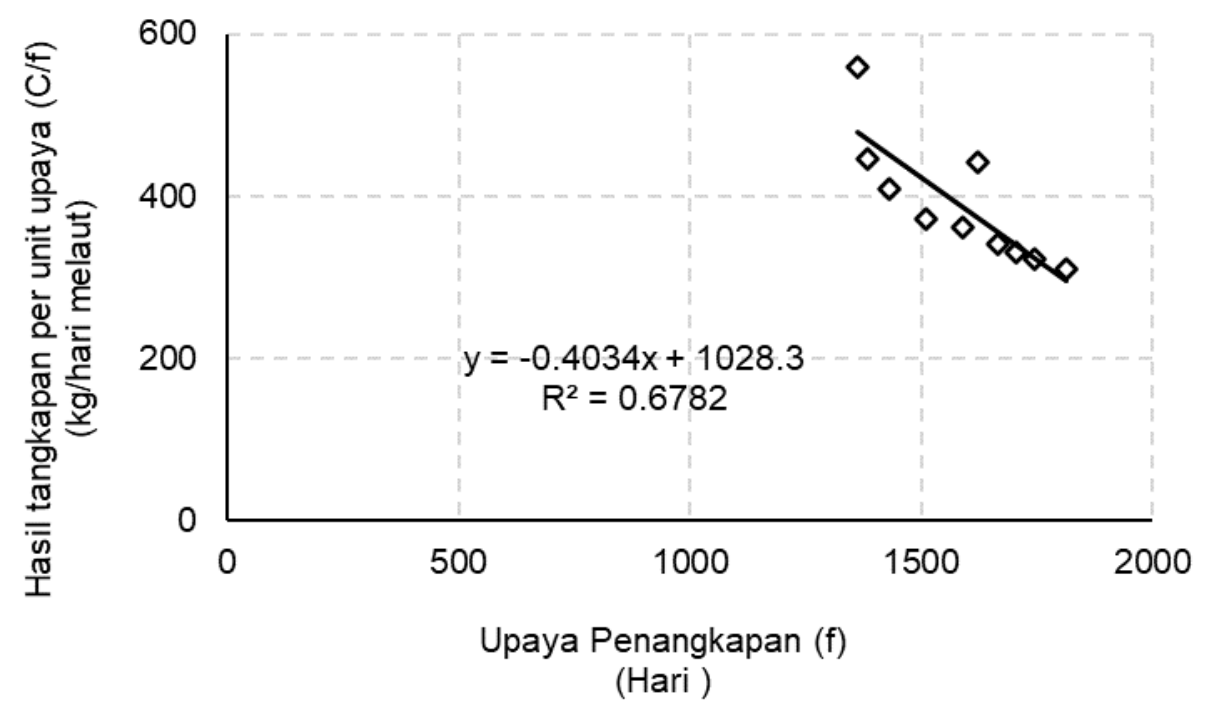

Gambar 3 Grafik analisis regresi antara hasil tangkapan per unit upaya $(y)$ dan upaya penangkapan $(x)$

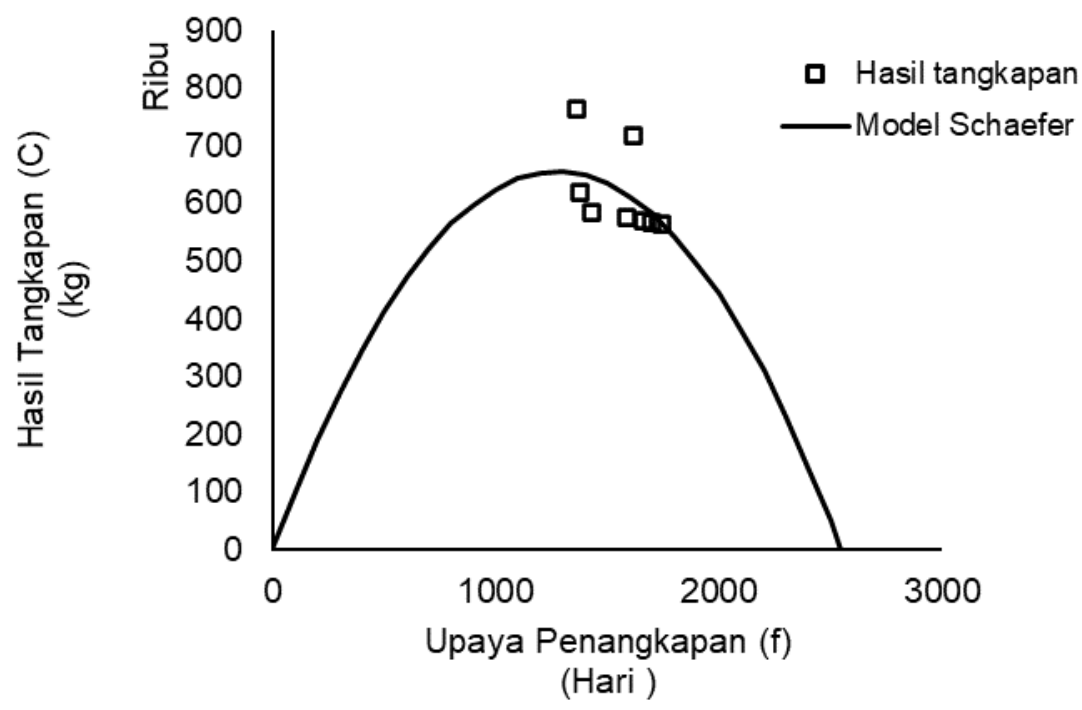

Gambar 4 Model surplus produksi Schaefer perikanan cakalang

Tabel 2 Perbandingan teknis strategi penangkapan

\begin{tabular}{clrr}
\hline No & Parameter & Feedback $\boldsymbol{H C R}$ & \multicolumn{1}{c}{ Schaefer } \\
\hline 1 & $J T B_{2021}$ atau $A B C_{2021}(\mathrm{~kg})$ & $561.875,21$ & $524.211,5$ \\
2 & $f_{J T B}$ atau $A B E_{2021}$ (hari) & 1.809 & 704 \\
\hline
\end{tabular}

\section{PEMBAHASAN}

Aplikasi feedback HCR merupakan aplikasi praktikal yang relatif sederhana tanpa membutuhkan estimasi biomasa stok ikan. Pada prinsipnya, aplikasi ini mempertimbangkan tren indeks kelimpahan stok dalam menentukan jumlah tangkapan yang aman secara biologi untuk dimanfaatkan $(A B C)$ yang untuk selanjutnya dijadikan dasar sebagai penetapan kuota tangkap (Ichinokawa et al. 2017; Harlyan et al. 2019).

Berdasarkan dokumentasi kegiatan penangkapan dalam kurun waktu tertentu sebelum dilakukan estimasi, informasi mengenai jumlah tangkapan yang aman secara biologi untuk dapat dimanfaatkan pada 
tahun ke-y $\left(A B C_{y}\right)$ dan jumlah upaya penangkapan yang dapat dilakukan pada tahun ke- $y\left(A B E_{y}\right)$ dengan mudah diperoleh. Dokumentasi kegiatan penangkapan dapat berupa data hasil tangkapan, upaya penangkapan dan hasil tangkapan per unit upaya yang telah sebelumnya dilakukan validasi tren. Pada banyak kasus, upaya penangkapan tidak dapat tervalidasi, sehingga indeks kelimpahan stok yang digunakan bisa berupa data hasil tangkapan (Ohshimo and Naya 2014; Harlyan et al. 2019).

Terkait dengan pengelolaan perikanan Indonesia dan beberapa negara di wilayah Asia Tenggara lainnya dengan keterbatasan data yang memenuhi syarat untuk dilakukan pengkajian stok (Harlyan et al. 2021), penggunaan aplikasi feedback HCR mampu memberikan informasi praktis dengan kebutuhan data yang lebih fleksibel dibandingkan dengan menggunakan pendekatan konvensional spesies tunggal seperti pendekatan dengan model surplus produksi (Chumchuen and Chumchuen 2019; Harlyan et al. 2019; Kvamsdal et al. 2016; Makino 2011).

Pengelolaan perikanan Indonesia seperti halnya pada pengelolaan perikanan di negara wilayah Asia Tenggara secara umum menggunakan sistem spesies tunggal pada beberapa SDI ekonomis penting (Chumchuen and Chumchuen 2019; Harlyan et al. 2019; Harlyan et al. 2021). Salah satu spesies SDI di Indonesia yang dikelola dengan menggunakan model surplus produksi adalah SDI cakalang. Hasil dari pengelolaan perikanan cakalang dengan sistem spesies tunggal terpublikasi mengenai status perikanan cakalang yang didaratkan di PPN Prigi (Setiyawan 2016; Nurdin 2017; Firdaus 2018; Tampubolon et al. 2019). Keseluruhan hasil penelitian menunjukkan status stok perikanan cakalang yang telah dikelola, namun tetap mengalami penurunan dari tahun ke tahun.

Pada penelitian ini digunakan dua strategi penangkapan yaitu aplikasi feedback $H C R$ dan model surplus produksi Schaefer untuk mengestimasi $A B C_{y}$ dan $A B E_{y}$. Berdasarkan hasil analisis feedback $H C R$, indeks kelimpahan stok perikanan cakalang dalam hal ini merupakan tren hasil tangkapan cakalang per hari melaut mengalami penurunan sejak tahun 2014 meski dengan tingkat fluktuasi yang relatif rendah. Menurut Magnusson (1992) dan Harlyan et al. (2019), historical catch yang ditunjukkan lewat level stok pada tren CPUE, memiliki peranan yang sangat penting untuk kebijakan dan strategi tangkap selanjutnya. Jika suatu perikanan memiliki level stok yang rendah maka perikanan harus memberikan kesempatan pada SDI untuk dapat pulih (Kleisner et al. 2013) dengan kuota tangkap yang tidak terlalu tinggi (Carruthers et al. 2014; Dowling et al. 2015; Harlyan et al. 2019).

Sejalan dengan hasil penelitian terdahulu (Setiyawan and Haryuni 2013; Setiyawan 2016; Firdaus 2018), model surplus produksi Schaefer yang digunakan pada penelitian ini menunjukkan tingkat pemanfaatan SDI cakalang selama 10 tahun terakhir (20102019) telah melebihi batas hasil tangkapan lestari. Hal yang sama terjadi pula pada upaya penangkapan yang digunakan untuk kegiatan penangkapan SDI cakalang telah melebihi upaya penangkapan yang digunakan untuk memperoleh hasil tangkapan lestari, meski telah dilakukan pengelolaan perikanan dengan menggunakan model surplus produksi.

Secara umum, hasil perhitungan aplikasi feedback HCR dan model surplus memberikan nilai jumlah tangkapan yang aman secara biologi untuk dimanfaatkan (JTB) hampir sama satu sama lain (Ichinokawa et al.2015). Keduanya menggunakan prinsip kehati-hatian dalam estimasi jumlah tangkapan yang diperbolehkan (Pedersen and Berg 2017). Aplikasi feedback HCR memberikan selisih relatif kecil terhadap model Schaefer yang cukup konservatif untuk penentuan nilai $J T B_{2021}$ atau $A B C_{2021}$ tersebut didasarkan bahwa referensi kelimpahan stok yang pada empat tahun terakhir cukup mampu memberikan nilai kuota tangkap yang cukup tinggi paling tidak di tahun 2021. Beberapa kajian terdahulu menyebutkan strategi tangkapan yang lebih konservatif umumnya mampu memenuhi tujuan pengelolaan perikanan jangka panjang (Carruthers 2018; Kleisner et al. 2013; Punt et al. 2016; Wiedenmann et al. 2016).

Disisi lain, perbandingan teknis nilai upaya penangkapan yang digunakan untuk menghasilkan hasil tangkapan yang aman secara biologi dimanfaatkan JTB $_{2021}$ atau $A B C_{2021}$ ) menunjukkan adanya selisih cukup tinggi sebesar lebih dari $50 \%$ antara kedua strategi penangkapan. Model Schaefer memberikan nilai upaya penangkapan $f_{M S Y}$ bahkan $f_{J T B}$ lebih rendah untuk dapat menghasilkan $C_{M S Y}$ maupun $C_{J T B}$. Hal ini terjadi 
karena model Schaefer ini merupakan model yang mampu precautionary approach yang cukup baik (Palomares and Pauly 2019; Varghese et al. 2020), jika nilai $f_{M S Y}$ yang dihasilkan mampu diasumsikan sebagai batas pemanfaatan yang harus dihindari. Namun, faktanya adalah pada banyak kasus kegiatan penangkapan melebihi upaya penangkapan yang telah ditentukan, sehingga proses pemulihan SDI tidak cukup mampu menghentikan resiko terjadinya penangkapan berlebih (Rosenberg et al. 2014; Falsone et al. 2021).

Pendugaan nilai $f_{M S Y}$ yang relatif rendah tidak cukup mampu mengatasi pemulihan SDI jika tidak dibarengi dengan pengelolaan teknis terpadu berupa kontrol pelaksanaan kuota tangkap (Harlyan et al. 2021; Omori et al. 2016). Kondisi perikanan multispesies dengan problematika agregasi spesies dalam pencatatan data perikanan jika dikelola dengan pendekatan konvensional spesies tunggal juga akan menghasilkan rekomendasi dengan tingkat validitas yang rendah (Yuniarta et al. 2017; Harlyan et al. 2019). Oleh karena itu, penggunaan feedback $H C R$ yang telah sebelumnya tervalidasi dapat menjadi alternatif strategi pengelolaan perikanan untuk digunakan pada perikanan dimana hanya tersedia data spesies tercampur (mixed-species data) (Harlyan et al. 2019).

\section{KESIMPULAN}

Hasil perhitungan aplikasi feedback $H C R$ dan model surplus memberikan nilai JTB hampir sama satu sama lain. Namun kedua strategi penangkapan memberikan hasil yang berbeda dalam menghasilkan upaya penangkapan yang digunakan untuk menghasilkan hasil tangkapan yang aman secara biologi dimanfaatkan dimana model Schaefer memberikan nilai upaya penangkapan $f_{M S Y}$ yang lebih rendah dibandingkan yang dihasilkan oleh feedback HCR. Meski demikian, pengelolaan spesies tunggal dengan tingkat kehati-hatian tinggi belum cukup mampu mengatasi pemulihan SDI.

\section{SARAN}

Diperlukan tren hasil tangkapan dan upaya penangkapan dengan selang waktu yang relatif panjang agar mampu mengkonfirmasi level stok suatu perikanan.
Selain itu penggunaan upaya penangkapan lain seperti jumlah trip, jumlah armada, atau jumlah alat tangkap dapat dilakukan untuk memastikan tingkat pemanfataan dan besarnya tekanan penangkapan.

\section{UCAPAN TERIMA KASIH}

Peneliti mengucapkan terimakasih kepada Fakultas Perikanan dan IImu Kelautan Universitas Brawijaya atas pemberian Dana Program Penelitian Hibah Guru Besar dan Doktor di lingkungan Fakultas Perikanan dan IImu Kelautan Universitas Brawijaya

\section{DAFTAR PUSTAKA}

Asia A, Santoso H, Purwanto Y, Tumiwa J, Zaini M. 2019. Kajian Keberlanjutan Perikanan Cakalang (Katsuwonus Pelamis) di Bitung. J BLUEFIN Fish. 1(1): 9-22.

Cadrin SX, Dickey-Collas M. 2015. Stock Assessment Methods for Sustainable Fisheries. ICES J Mar Sci. 72(1): 1-6. doi:10.1093/icesjms/fsu228.

Carruthers TR, Punt AE, Walters CJ, MacCall A, McAllister MK, Dick EJ, Cope J. 2014. Evaluating Methods for Setting Catch Limits in Data-Limited Fisheries. Fish Res. 153: 48-68. doi:10.1016/j.fishres.2013.12.014.

Carruthers TR. 2018. A multispecies CatchRatio Estimator of Relative Stock Depletion. Fish Res. 197: 25-33. doi:10.1016/j.fishres.2017.09.017.

Chumchuen W, Chumchuen SV. 2019. Development of Albacore Tuna Fishery and Estimation of Allowable Biological Catch for Resource Management in the Indian Ocean. Fish people. 17(3): 34-40. http://hdl.handle.net/20.500.12066/5795.

Dowling NA, Dichmont CM, Haddon M, Smith DC, Smith ADM, Sainsbury K. 2015. Empirical Harvest Strategies for DataPoor Fisheries: A Review of the Literature. Fish Res. 171: 141-153. doi:10.1016/j.fishres.2014.11.005.

Falsone F, Scannella D, Geraci ML, Gancitano V, Vitale S, Fiorentino F. 2021. How Fishery Collapses: The Case of Lepidopus caudatus (Pisces: Trichiuridae) 
in the Strait of Sicily (Central Mediterranean). Front Mar Sci. 7(584601):1-9. doi: $10.3389 /$ fmars.2020.584601

Firdaus M. 2018. Profil Perikanan Tuna dan Cakalang di Indonesia. Bul IIm Mar Sos Ekon Kelaut dan Perikan. 4(1): 23-32.

Harlyan LI. 2019. Purse Seine Fishery Management in Malaysia: an Output Control for Sustainable Fisheries [Disertasi]. Hakodate: Hokkaido University. http://hdl.handle.net/2115/75831\%0A.

Harlyan LI, Matsuishi TF, Md Saleh MF. 2021. Feasibility of a Single-Species Quota System for Management of the Malaysian Multispecies Purse-Seine Fishery. Fish Manag Ecol. 28(2): 126-137. doi:10.1111/fme.12470.

Harlyan LI, Wu D, Kinashi R, Kaewnern M, Matsuishi T. 2019. Validation of a Feedback Harvest Control Rule in DataLimited Conditions for Managing Multispecies Fisheries. Can J Fish Aquat Sci. 76(10): 1885-1893. doi:10.1139/cjfas-2018-0318.

Hilborn R, Ovando D. 2014. Reflections on the Success of Traditional Fisheries Management. ICES J Mar Sci. 71(5): 1040-1046. doi:10.1093/icesjms/fsu034.

Hilborn R, Walters CJ, editors. 1992. Quantitative Fisheries Stock Assessment: Choice, Dynamics and Uncertainty. Springer US.

Hoshino E, Milner-Gulland EJ, Hillary RM. 2012. Bioeconomic Adaptive Management Procedures for Short-Lived Species: A Case Study of Pacific Saury (Cololabis saira) and Japanese Common Squid (Todarodes pacificus). Fish Res. 121-122 (Supplement C): 17-30. doi:10.1016/j.fishres.2012.01.007.

Ichinokawa M, Okamura $\mathrm{H}$, Kurota $\mathrm{H}$, Yukami $\mathrm{R}$, Tanaka H, Shibata $\mathrm{Y}$, Ohshimo S. 2015. Searching for Optimum Management Procedures by Quantifying Management Objectives for Japanese Domestic Fishery Stocks Without Stock Biomass Estimation. Nippon Suisan Gakkaishi. 81(2): 206-218. doi:10.2331/suisan.81.206 [In Japanese].

Ichinokawa M, Okamura H, Kurota H. 2017. The Status of Japanese Fisheries Relative to Fisheries Around the World. ICES J Mar Sci. 74(5): 1277-1287. doi:10.1093/icesjms/fsx002.

Kementerian Kelautan dan Perikanan. 2014. Peraturan Menteri Kelautan dan Perikanan Republik Indonesia No 18 Tahun 2014 tentang Wilayah Pengelolaan Perikanan. Jakarta.

Kementerian Kelautan dan Perikanan. 2016. Keputusan Menteri Kelautan dan Perikanan Republik Indonesia No 47 Tahun 2016 tentang Estimasi Potensi, Jumlah Tangkapan yang Diperbolehkan, dan Tingkat Pemanfaatan Sumber Daya Ikan di Wilayah Pengelolaan Perikanan Negara Republik Indonesia. Jakarta.

Kementerian Kelautan dan Perikanan. 2020. Triwulan I 2020, Nilai Ekspor Perikanan Capai USD 1,24 Miliar. [internet]. [diunduh 2021 Maret 4]. Tersedia pada: https://kkp.go.id/artikel/18769-triwulan-i2020-nilai-ekspor-perikanan-capai-usd124-miliar

Kleisner K, Zeller D, Froese R, Pauly D. 2013. Using Global Catch Data for Inferences on the World's Marine Fisheries. Fish Fish. 14(3): 293-311. doi:10.1111/j.14672979.2012.00469.x. doi:10.1111/j.14672979.2012.00469.x.

Kvamsdal SF, Eide A, Ekerhovd N-A, Enberg K, Gudmundsdottir A, Hoel AH, Mills KE, Mueter FJ, Ravn-Jonsen L, Sandal LK, et al. 2016. Harvest control rules in modern fisheries management. Elem Sci Anth. 4(000114):1-22. doi:10.12952/journal.elementa.000114.

Ma'mun A, Priatna A, Hidayat T, Nurulludin. 2017. Distribusi dan Potensi Sumber Daya Ikan Pelagis di Wilayah Pengelolaan Perikanan Negara Republik Indonesia 573 (WPP NRI 573) Samudera Hindia. J Penelit Perikan Indones. 23(1): 47-56.

Magnusson KG. 1992. A Feedback and Probing Strategy to Regulate Harvesting from a Renewable Resource. Math Med Biol. 9: 43-65. doi:10.1093/imammb/9.1.43.

Makino M. 2011. Fisheries management in Japan. 1st ed. Japan: Springer.

Newman SJ, Brown JI, Fairclough D V., Wise BS, Bellchambers LM, Molony BW, Lenanton RCJ, Jackson G, Smith KA, Gaughan DJ. 2018. A Risk Assessment 
and Prioritisation Approach to the Selection of Indicator Species for the Assessment of Multi-Species, Multi-Gear, Multi-Sector Fishery Resources. Mar Policy. 88(Supplement C): 11-22. doi:10.1016/j.marpol.2017.10.028.

Nurdin E. 2017. Perikanan Tuna Skala Rakyat (Small Scale) di Prigi, Trenggalek-Jawa Timur. BAWAL Widya Ris Perikan Tangkap. 2(4): 177-183.

Ohshimo S, Naya M. 2014. Management Strategy Evaluation of Fisheries Resources in Data-Poor Situations Using an Operating Model Based on a Production Model. Japan Agric Res $Q$ JARQ. 48(2): 237-244. doi:10.6090/jarq.48.237.

Omori KL, Hoenig JM, Luehring MA, BaierLockhart K. 2016. Effects of Underestimating Catch and Effort on Surplus Production Models. Fish Res. 183: 138-145.

Palomares MLD, Pauly D. 2019. On the Creeping Increase of Vessels' Fishing Power. Ecol Soc. 24(3): 31

Pedersen MW, Berg CW. 2017. A Stochastic Surplus Production Model in Continuous Time. Fish Fish. 18(2): 226-243.

Punt AE, Butterworth DS, Moor CL, Oliveira D, A JA, Haddon M. 2016. Management Strategy Evaluation: Best Practices. Fish Fish. 17(2): 303-334. doi:10.1111/faf.12104.

Rosenberg AA, Fogarty MJ, Cooper AB, Dickey-Collas M, Fulton EA, Gutieerrez N, Hyde KJ, Kleisner KM, Kristiansen T, Longo C. 2014. Developing New Approaches to Global Stock Status Assessment and Fishery Production Potential of the Seas. Rome: FAO Report No.1086.

Setiyawan A. 2016. Pendugaan Tingkat Pemanfaatan Ikan Cakalang (Katsuwonus pelamis) di Perairan Prigi, Jawa Timur. Depik. 5(1): 7-11. doi:10.13170/depik.5.1.3831.

http://jurnal.unsyiah.ac.id/depik/article/vie w/3831.

Setiyawan A, Haryuni STW. 2013. Perkembangan Hasil Tangkapan Per
Upaya dan Pola Musim Penangkapan Ikan Cakalang (Katsuwonus pelamis) di Perairan Prigi, Provinsi Jawa Timur. Depik. 2(2): 76-81. doi:10.13170/depik.2.2.726.

http://jurnal.unsyiah.ac.id/depik/article/vie w/726.

Shertzer KW, Prager MH, Vaughan DS, Williams EH. 2008. Fishery Models. In: Jørgensen SE, Fath BDBT-E of E, editors. Oxford: Academic Press. p. 1582-1593. http://www.sciencedirect.com/science/arti cle/pii/B9780080454054006686.

Sparre P, Venema SC. 1992. Introduction to Tropical Fish Stock Assessment. Part 1: Manual. Rome.

Tampubolon PAR., Agustina M, Fahmi Z. 2019. Aspek Biologi Ikan Tembang (Sardinella Gibbosa Bleeker, 1849) di Perairan Prigi dan Sekitarnya. BAWAL Widya Ris Perikan Tangkap. 11(3): 151159. doi:10.15578/bawal.11.3.2019.151159.

Tanaka S. 1980. A Theoretical Consideration on the Management of a Stock-Fishery System by Catch Quota and on its Dynamical Properties. Nippon Suisan Gakkaishi. 46(12): 1477-1482. doi:10.2331/suisan.46.1477.

Varghese E, Sathianandan TV, Jayasankar J, Kuriakose S, Mini KG, Muktha M. 2020. Bayesian State-Space Implementation of Schaefer Production Model for Assessment of Stock Status for Multi-gear Fishery. J Indian Soc Agric Stat. 74(1): 33-40.

Wiedenmann J, Wilberg M, Sylvia A, Miller T. 2016. An Evaluation of Acceptable Biological Catch (ABC) Harvest Control Rules Designed to Limit Overfishing. Can $J$ Fish Aquat Sci. 74(7): 1028-1040. doi:10.1139/cjfas-2016-0381.

Yuniarta S, van Zwieten PAM, Groeneveld RA, Wisudo SH, Van Lerland EC. 2017. Uncertainty in Catch and Effort Data of Small- and Medium-Scale Tuna Fisheries in Indonesia: Sources, Operational Causes and Magnitude. Fish Res. 193: 173-183. doi:10.1016/j.fishres.2017.04.009. 